\title{
STUDI PENDAHULUAN PADA UPAYA PENGEMBANGAN LABORATORIUM VIRTUAL BAGI CALON GURU FISIKA
}

\author{
Gunawan, Ahmad Harjono, Hairunnisyah Sahidu \\ Program Studi Pendidikan Fisika \\ Universitas Mataram \\ Mataram, Indonesia \\ Email : gunawan@unram.ac.id
}

\begin{abstract}
The purpose of this study was to develop a model of virtual labs on some concepts of physics. In this article will describe some of the findings of the preliminary study carried out in the framework of the development of the virtual laboratory model. Data were collected through observation, questionnaires, interviews, and studies related documents. The results showed that a number of problems related to the lecture held, particularly with respect to the selection method of teaching on certain concepts, issues related to the activities of laboratory experiments, the description of the physics of matter that is difficult for students. Results of this study are expected to be the basis for the development of the model as well as efforts to improve the quality of learning physics, particularly for prospective teachers of physics.
\end{abstract}

Keywords: laboratory activity, virtual lab

\section{Pendahuluan}

Salah satu permasalahan penting dalam pembelajaran fisika adalah rendahnya kualitas pembelajaran pada berbagai jenjang pendidikan. Kualitas proses dan hasil belajar fisika di sekolah ditentukan oleh banyak faktor, salah satunya ketersediaan sarana laboratorium. Kegiatan laboratorium merupakan hal yang krusial dalam pembelajaran fisika, karena melalui kegiatan laboratorium aspek produk, proses, dan sikap dapat lebih dikembangkan.

Keberhasilan penyelenggaraan kegiatan laboratorium sangat bergantung pada peran guru. Sayangnya, hasil penelitian menunjukkan bahwa kemampuan guru fisika dalam merancang dan melaksanakan percobaan masih relatif rendah. McDermot [1] menyatakan bahwa salah satu faktor penting yang mempengaruhi rendahnya kinerja pendidikan IPA, termasuk fisika adalah kurangnya guru-guru yang dipersiapkan dengan baik. Hal ini menunjukkan bahwa upaya memperbaiki kualitas pendidikan guru harus terus-menerus dilakukan.

Salah satu faktor yang mempengaruhi keberhasilan kegiatan laboratorium adalah sumber daya yang mencakup bahan dan peralatan, ruang dan perabot, tenaga laboran, serta teknisi. Ketersediaan sumber daya tersebut secara memadai jelas menunjang pelaksanaan kegiatan laboratorium, sebaliknya keterbatasan alat dan bahan sering menjadi alasan bagi guru untuk tidak melakukan kegiatan laboratorium. Ketersediaan alat dan bahan laboratorium yang dimiliki sekolah dapat diatasi, salah satunya dengan pengembangan model laboratorium virtual.

Kegiatan praktikum fisika juga dihadapkan pada berbagai masalah, diantaranya mahalnya peralatan laboratorium, terbatasnya sarana laboratorium yang dimiliki sekolah, serta kesulitan melakukan praktikum pada berbagai konsep fisika yang abstrak. Pada konsep fisika yang abstrak, terdapat kesulitan untuk memvisualisasikan atau menampilkan proses fisis secara langsung melalui kegiatan laboratorium yang riil. Kondisi ini menyebabkan rendahnya tingkat penguasaan konsep fisika peserta didik. Kesulitan dalam memahami konsep fisika yang abstrak dan sulit divisualisasikan dapat diatasi, salah satunya dengan pemanfaatan teknologi komputer.

Perkembangan teknologi informasi menyediakan kesempatan untuk membangun dan menggunakan animasi komputer untuk pembelajaran yang berorientasi pada representasi mikroskopik. Hal ini dapat diwujudkan dengan bantuan animasi komputer karena animasi komputer dapat memvisualisasikan 
proses-proses abstrak yang mustahil dilihat atau dibayangkan.

Perkembangan di bidang ICT memberikan pengaruh yang signifikan terhadap bagaimana proses pembelajaran fisika, khususnya pada efektivitas pembelajaran, efisiensi waktu dan fasilitas pendukung pembelajaran lainnya. Teknologi komputer dapat diadaptasi menjadi sebuah pendekatan pembelajaran yang aktif. Teknologi komputer memungkinkan adanya perpaduan antara tatap-muka (face to face) dengan pembelajaran online. Beberapa hal yang perlu dipertimbangkan antara lain pendekatan yang mungkin diterapkan, strategi, teknik, dan peralatan yang ada [2]. Teknologi komputer yang digunakan dapat menggunakan format online maupun offline. Teknologi komputer dapat digunakan mendukung pembelajaran berbasis ICT, eksperimen virtual, asesmen berbasis ICT, maupun penggunaannya sebagai media pembelajaran [3].

Beberapa penelitian terdahulu juga menunjukkan sejumlah kelebihan multimedia dalam pembelajaran fisika. McKagan [4], menemukan bahwa penggunaan multimedia efektif dalam pembelajaran konsep mekanika kuantum terbukti membantu mahasiswa membangun model mental dan intuisi tentang mekanika kuantum meliputi representasi visual dari konsep abstrak dan proses mikroskopik yang tidak dapat diobservasi secara langsung. Penelitian ini juga menunjukkan bahwa simulasi yang digunakan efektif dalam membantu mahasiswa belajar dan telah mengungkapkan pengertian baru yang mendalam baru pada cara pikir mereka tentang mekanika kuantum.

\section{TINJAUAn PUSTaKa}

Penggunaan media pembelajaran termasuk dalam kegiatan laboratorium virtual dapat melalui pemanfaatan internet dalam e-learning maupun penggunaan program komputer sebagai media interaktif. Para peneliti menemukan bahwa ada berbagai cara peserta didik dalam memproses informasi yang bersifat unik. Sebagian lebih mudah memproses informasi visual, sebagian lain lebih mudah kalau ada suara, dan sebagian lain akan memahami dengan mudah atau lebih baik jika melakukannya dengan praktek. Penggunaan laboratorium virtual dalam pembelajaran fisika diharapkan dapat meningkatkan penguasaan konsep dan keterampilan berpikir kritis peserta didik.

Suatu simulasi komputer yang memungkinkan adanya fungsi percobaan laboratorium pada suatu komputer dinamakan virtual laboratory. Virtual laboratory merupakan sistem yang dapat digunakan untuk mendukung sistem praktikum yang berjalan secara konvensional. Virtual laboratory ini biasa disebut dengan virtual-lab. Diharapkan dengan adanya virtual-lab ini dapat memberikan kesempatan kepada mahasiswa khususnya untuk melakukan praktikum melalui akses internet maupun menggunakan software pembelajaran yang disediakan. Hal ini menjadi pembelajaran efektif karena mahasiswa dapat belajar sendiri secara aktif tanpa bantuan instruktur ataupun asisten seperti sistem yang berjalan.

Dengan format tampilan berbasis web cukup membantu mahasiswa untuk dapat mengikuti praktikum secara mandiri. Virtual laboratory dapat dikategorikan menjadi 5, yaitu: 1) simulasi klasik yang berisi unsur-unsur percobaan laboratorium tertentu dan tersedia di tempat itu (simulations). 2) simulasi klasik yang berisi unsur-unsur percobaan laboratorium tertentu dan dapat diakses secara online (cyber laboratory). 3) simulasi yang mencoba menghadirkan percobaan laboratorium yang sedapat mungkin sesuai dengan eksperimen sesungguhnya (virtual labs). 4) simulasi laboratorium yang mengadakan percobaan menggunakan virtual reality techniques (VR Labs) 5). eksperimen riil yang dikendalikan via jaringan/internet (remote labs) [5].

Pemanfaatan simulasi komputer dalam virtual laboratory fisika diharapkan dapat meningkatkan pemahaman konsep calon guru. Simulasi komputer dapat digunakan sebagai alternatif media pembelajaran karena dapat membantu siswa mengatasi kelemahannya dalam teori dan pengembangan pemahaman konsep fisika. 
Finkelstein [6], mengatakan bahwa komputer dapat digunakan untuk menunjang pelaksanaan praktikum fisika baik untuk mengumpulkan data, menyajikan, dan mengolah data. Selain itu, komputer juga dapat digunakan untuk memodifikasi eksperimen dan menampilkan eksperimen lengkap dalam bentuk virtual.

Penggunaan komputer dalam proses belajar mengajar memberikan beberapa dampak positif, diantaranya: kontribusi pada sebuah evolusi cara siswa belajar, memperkaya dan memperluas pengalaman belajar siswa, menyediakan alat yang kuat bagi siswa untuk eksplorasi web, memberikan kontribusi pada evolusi teori-teori belajar, dan lain sebagainya [7].

Pada abad XXI, terdapat beberapa keterampilan yang menjadi fokus perhatian, yaitu pemecahan masalah, keterampilan berpikir kritis, serta literasi ICT. Beberapa keterampilan belajar menggunakan ICT, diantaranya: (1) keterampilan dalam media dan informasi, mulai dari menganalisis, mengakses, mengatur, mengintegrasikan, mengevaluasi dan membuat informasi dalam berbagai bentuk dan media. Juga keterampilan dalam aturan penggunaan media dalam masyarakat, (2) keterampilan komunikasi, meliputi komunikasi lisan, komunikasi tulis, dan komunikasi melalui multimedia dalam berbagai bentuk dan konteksnya, (3) keterampilan interpersonal dan self-direction. Menjadi lebih produktif dalam menyelesaikan tugas dan mengembangkan minat dalam meningkatkan keterampilan secara mandiri.

Alasan penggunaan komputer dalam pembelajaran, antara lain: (1) kemampuan komputer untuk menyajikan informasi dalam bentuk multimedia (teks, gambar, audio, video, animasi, simulasi) dan aspek interaktif, (2) komputer dapat diprogram untuk melakukan perhitungan, memeriksa hasil tes dan memberikan umpan balik, (3) teknologi internet memungkinkan bahan ajar dapat diakses kapan saja, dimana saja dan oleh siapa saja yang terhubung ke internet [8].

Proyek multimedia mendorong siswa untuk bekerja dalam kelompok, mengungkapkan pengetahuan mereka dalam berbagai cara, memecahkan masalah, merevisi karya mereka sendiri, dan membangun pengetahuan. Siswa memiliki kesempatan untuk belajar dan menerapkan keterampilan dunia nyata. Mereka belajar nilai kerja sama tim; dampak dan pentingnya media yang berbeda, termasuk masalah desain, media kesesuaian dan validitas, dan hukum hak cipta; tantangan berkomunikasi dengan peserta yang berbeda; pentingnya penelitian, perencanaan, dan keterampilan organisasi; pentingnya presentasi dan keterampilan berbicara; dan bagaimana menerima dan memberikan umpan balik yang konstruktif. Membuat proyek multimedia membantu untuk memperkuat keterampilan teknologi siswa dan mempersiapkan mereka untuk tuntutan karir masa depan [3]

Berdasarkan hasil penelitian Gunawan et al [9], dapat disimpulkan bahwa penguasaan konsep mahasiswa yang belajar menggunakan multimedia interaktif lebih tinggi dibandingkan dengan mahasiswa yang diajarkan secara konvensional. Pembelajaran menggunakan multimedia interaktif membantu mahasiswa untuk mengingat kembali konsep dasar yang pernah diterima sebelumnya lebih baik dibandingkan pembelajaran secara konvensional. Hal ini ditunjukkan adanya perbedaan yang signifikan pada konsep-konsep dasar setiap materi antara yang belajar dengan multimedia interaktif dengan mahasiswa yang belajar secara konvensional.

Simulasi komputer dapat digunakan sebagai alternatif media pembelajaran karena dapat membantu siswa mengatasi kelemahannya dalam teori dan pengembangan pemahaman konsep fisika. Zacharia [10], menyatakan bahwa penggunaan simulasi interaktif membantu mahasiswa memvisualisasikan masalah dan pemecahannya, juga dapat menumbuhkan sikap positif terhadap fisika. Penggunaan multimedia interaktif dapat lebih meningkatkan kemampuan inferensi logika dan kemampuan menarik kesimpulan mahasiswa [11], begitupun halnya dengan penggunaan laboratorium virtual. Penggunaan laboratorium virtual dapat membuat mahasiswa berpikiran lebih terbuka dan memotivasi mereka terus mencoba menemukan secara 
mandiri konsep fisika yang diharapkan [12]. beberapa Kit percobaan seperti mekanika, optika, Laboratorium virtual juga terbukti membantu mahasiswa belajar dalam penalaran logis sehingga kemampuan inferensi logika dan kemampuan menarik kesimpulan mahasiswa mengalami peningkatan [13].

\section{METODE PENELITIAN}

Penelitian ini termasuk jenis penelitian dan pengembangan (research and development). Jenis penelitian R\&D adalah suatu proses yang digunakan untuk mengembangkan dan memvalidasi produkproduk pendidikan [14]. Dalam penelitian ini akan dikembangkan suatu produk virtual laboratory untuk pembelajaran fisika. Secara umum penelitian dilakukan dalam 3 tahapan, yaitu: tahap studi pendahuluan, tahap pengembangan desain model laboratorium virtual, dan tahap validasi dan evaluasi model.

Saat ini penelitian masih dalam tahap studi pendahuluan. Pada tahap ini metode yang digunakan adalah metode deskriptif, untuk menggambarkan fenomena-fenomena yang ada secara sistematis, faktual, akurat, dan apa adanya. Peneliti secara langsung dapat berhubungan dengan responden dan objek lainnya yang berkaitan dengan permasalahan yang diteliti. Responden yang dilibatkan pada tahap ini adalah calon guru dan guru-guru fisika di sekolah menengah.

\section{HASIL DAN PEMBAHASAN}

Tahap ini dilakukan dengan menerapkan pendekatan deskriptif kualitatif. Pada tahap ini dikumpulkan sejumlah informasi terkait fasilitas laboratorium fisika dan laboratorium komputer pada beberapa LPTK di Nusa Tenggara Barat. Informasi tersebut diantaranya terkait ketersediaan, kualitas dan kuantitas sarana prasarana pendukung hingga frekuensi percobaan yang rutin maupun pernah dilaksanakan. Hasil observasi menunjukkan bahwa peralatan laboratorium fisika pada beberapa LPTK di NTB dalam kondisi yang tidak memadai, dengan peralatan pendukung eksperimen yang sangat terbatas. Umumnya peralatan yang tersedia hanya terdiri dari listrik dan magnet.

Wawancara juga dilakukan dengan dosen, guru, dan calon guru untuk mengetahui beberapa permasalahan yang berkaitan dengan ketersediaan peralatan laboratorium fisika dan mengetahui tanggapannya tentang rencana penelitian yang akan dilakukan. Selain wawancara, juga diberikan angket tanggapan tentang beberapa permasalahan pembelajaran fisika.

Berdasarkan data angket tersebut dapat diketahui bahwa sebagian besar responden menyatakan masih banyak kegiatan eksperimen yang harusnya dilakukan tetapi 'batal', karena tidak tersedianya peralatan yang memadai. Kondisi ini kemudian berimplikasi pada kurang optimalnya pembelajaran yang dilaksanakan. Mahasiswa umumnya akan lebih mampu menyelesaikan soal-soal hitungan dibandingkan soal yang menguji penguasaan konsep teoritis, apalagi yang terkait dengan permasalahan proses fisis yang harusnya bisa diamati atau dieksperimenkan di laboratorium.

Pada tahap ini juga dilakukan analisis media yang dapat dikembangkan, hingga analisis konsep fisika yang relevan serta kemampuan pemecahan masalah yang dapat dikembangkan. Selain itu, beberapa literatur dan hasil-hasil penelitian terkini dianalisis untuk mendapatkan gambaran peluang pengembangan. Sejumlah temuan dan hasil analisis tersebut selanjutnya dijadikan bahan pertimbangan dalam mengembangkan draft model laboratorium virtual fisika.

Berdasarkan analisis yang dilakukan terhadap konsep-konsep dalam fisika dapat diketahui bahwa fisika terdiri dari konsep-konsep abstrak, konsep berdasarkan prinsip, dan konsep abstrak dengan contoh konkrit. Selain analisis pada konsep fisika, juga dilakukan analisis pada topik apa saja yang perlu dan bisa dipraktikumkan secara virtual. Analisis tidak hanya dilakukan pada buku-buku teks fisika di perguruan tinggi, tapi juga dilakukan pada buku-buku fisika di sekolah menengah. Hal ini dimaksudkan agar model virtual 
laboratory yang akan dikembangkan lebih bermanfaat karena tidak hanya digunakan di perguruan tinggi, tapi juga di sekolah menengah. Hal ini didasarkan pada pertimbangan tingkat kemanfaatan model yang akan dibuat, karena materi-materi dalam sub topik ini tidak hanya dipelajari di perguruan tinggi, tapi juga di sekolah menengah.

Selain analisis pada materi dan praktikum yang mungkin dikembangkan, dalam studi pendahuluan ini juga telah diperoleh sejumlah data yang berkaitan dengan problematika pembelajaran dan praktikum fisika di sekolah maupun di LPTK. Data diperoleh melalui angket dan studi dokumen. Angket dibagikan kepada mahasiswa calon guru serta guru-guru fisika di sekolah menengah. Hal ini dimaksudkan untuk mengetahui kondisi dan permasalahan riil yang dihadapi oleh mahasiswa calon guru maupun guruguru fisika berkaitan dengan pembelajaran dan kegiatan laboratorium fisika.

Berdasarkan data angket yang telah disebarkan untuk mengetahui persepsi awal calon guru tentang pembelajaran dan rencana pengembangan virtual laboratory fisika dapat diketahui bahwa sebagian besar (83\%) berpendapat bahwa konsep dalam fisika termasuk konsep yang sukar dan susah dipahami. Padahal konsep-konsep fisika sangat diperlukan dalam aplikasi teknologi. Semua responden menyatakan setuju dengan pentingnya peranan fisika dalam mendukung perkembangan teknologi dan informasi. Untuk ketersediaan alat dan sarana lain yang menunjang pelaksanaan praktikum fisika di sekolah, sebagian besar responden (91\%) menyatakan bahwa alat untuk praktikum fisika belum memadai, sedangkan lainnya (sekitar 9\%) menyatakan ragu-ragu. Semua responden mendukung ide pengembangan virtual laboratory fisika untuk mendukung pembelajaran fisika di sekolah.

Menurut responden penggunaan virtual laboratory selain efisien dan murah, juga dapat membantu pemahaman konsep fisika, keterampilan berpikir, dan kemampuan pemecahan masalah peserta didik. Secara umum responden menyatakan bahwa beberapa konsep dalam fisika dianggap sulit, abstrak, dan sulit dipraktikumkan secara riil. Selama ini praktikum fisika tidak pernah dilakukan di sekolah menengah karena keterbatasan alat yang dimiliki.

\section{PENUTUP}

Berdasarkan analisis dan pembahasan di atas dapat disimpulkan bahwa peralatan pendukung eksperimen fisika di sekolah maupun di LPTK belum memadai untuk mendukung pembelajaran. Model laboratorium perlu dikembangkan sebagai solusi terbatas atau tidak tersedianya peralatan laboratorium yang memadai. Sebagian besar responden menyatakan konsep fisika yang abstrak perlu divisualisasikan, beberapa tema dikembangkan sesuai kebutuhan di sekolah dan LPTK pada konsep yang belum memiliki software laboratorium virtual.

\section{UCAPAN TERIMA KASIH}

Penulis menyampaikan ucapan terima kasih yang sebesar-besarnya kepada DP2M Dikti Kemendikbud yang telah memfasilitasi pembiayaan penelitian ini melalui Skim Penelitian Strategis Nasional Tahun 2015. Ucapan terima kasih juga kami sampaikan kepada pihak lain yang telah mendukung menyiapkan data, dan memberikan tinjauan kritis guna penyempurnaan tulisan ini.

\section{REFERENSI}

[1] McDermott. (1990). A Perspective on Teacher Preparation in Physics and Other Sciences. American Journal of Physics. Vol 58 No.8

[2] Garrison, D.R \& Vaughan, N.D., (2008). Blended Learning in Higher Education. San Fransisco: John Willey \& Sons, Inc.

[3] Gunawan (2015). Model Pembelajaran Berbasis ICT. Mataram: FKIP Unram Press.

[4] McKagan et al. (2008). "Developing and Researching PhET simulations for Teaching Quantum Mechanics". American Journal of Physics, (76) pp. 406 - 417.

[5] Harms, U. Virtual and Remote Labs in Physics Education. Paper presented at Second European Conference on Physics Teaching in Engineering Education, Budapest, Jun. 2000.

[6] Finkelstein, et.al. (2005). "When Learning About the Real World Is Better Done Virtually: A Study 
of Subtituting Computer Simulations for

Laboratory Equipment". Physics Education Research. APS (1) $1-8$.

[7] Ivers, Karen \& Barron, Ann. (2002). Multimedia Projects In Education: Designing, Producing, and Assessing. Westport, CT : A Division of Greenwood Publishing Group, Inc.

[8] Munir (2001). Aplikasi Multimedia dalam Proses Belajar Mengajar. Mimbar Pendidikan XX (3). Universitas Pendidikan Indonesia.

[9] Holmes, B \& Gardner, J. (2006). E-Learning: Concepts and Practice. London: Sage Publications Ltd.

[10] Zacharia, Z. \& Anderson, O.R. (2003). The Effects of an Interactive Computer-Based Simulation Prior to Performing A Laboratory Inquiry-Based Experiment on Students' Conceptual Understanding of Physics. American Journal of Physics, 71(6), 618-629.

[11] Gunawan, et al. (2014). Penggunaan Multimedia Interaktif dalam Pembelajaran Fisika dan Implikasinya Pada Penguasaan Konsep Mahasiswa. Jurnal Pijar MIPA, Vol IX Nomor 1: $15-19$

[12] Gunawan \& Liliasari (2012). Model Virtual Laboratory Fisika Modern untuk Meningkatkan Disposisi Berpikir Kritis Calon Guru. Jurnal
Ilmiah Cakrawala Pendidikan. Th. XXXI, No. 2 : 185-199.

[13] Gunawan., Setiawan. A, \& Widyantoro D.H (2013). Model Virtual Laboratory Fisika Modern untuk Meningkatkan Keterampilan Generik Sains Calon Guru. Jurnal Pendidikan dan Pembelajaran. Vol. 20, No. 1 : 25-32.

[14] Borg, W. R and Gall, M. D. (2003). Educational Research: An Introduction. New York: Longman, Inc.

\section{Biografi Penulis}

Gunawan, lahir di Gontar (Sumbawa) pada tanggal 1 Mei 1981. Penulis menyelesaikan pendidikan S1 pada Program Studi Pendidikan Fisika FKIP Unram pada tahun 2003. Pendidikan S2 dan S3 pada program studi Pendidikan Fisika di Universitas Pendidikan Indonesia. Sejak menyelesaikan program doktor pada Januari 2011, penulis aktif pada beberapa penelitian dan pengabdian kepada Masyarakat. Saat ini penulis bekerja sebagai Dosen Pendidikan Fisika, FKIP Unram. Fokus penelitian beberapa tahun terakhir pada pengembangan media pembelajaran berbasis ICT dan keterampilan berpikir tingkat tinggi. 